\title{
REAL OPTIONS
}

\section{KremLjaK, Z. \& MEZA, P.}

Abstract: Research work of Black, Scholes and Merton (1973) brought to a method, which enabled appropriate evaluation of options in the circumstances of uncertainty. This resulted in great increase of research in the field of evaluating financial assets. A possibility of evaluating so called financial options was not interesting only to academics but was also accepted in the field of business systems. This is a survey of basic terms and logic for evaluating financial options.

Key words: real options, call option, put option, applicability, option chain
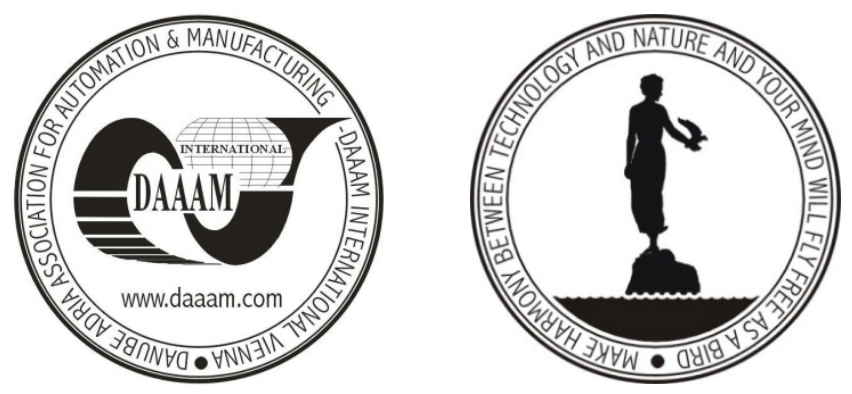

Authors' data: Dr. Kremljak, Z[vonko]*;Dr. Meza, P[eter]**, *Ministry of Economy Slovenia, Kotnikova 5, 1000, Ljubljana, Slovenia, ** Mednarodna fakulteta za družbene in poslovne študije - Celje, Mariborska cesta 7, 3000 Celje, Slovenia, zvonko.kremljak@s5.net, info@mfdps.si

This Publication has to be referred as: Kremljak, Zvonko] \& Meza, P[eter] (2008). Real Options, Chapter 35 in DAAAM International Scientific Book 2008, pp. 409424, B. Katalinic (Ed.), Published by DAAAM International, ISBN 978-3-90150966-7, ISSN 1726-9687, Vienna, Austria

DOI: $10.2507 /$ daaam.scibook.2008.35 